\title{
Cultivation of College English Autonomous Learning Ability for Navigation Majors
}

\author{
Yuan Gao \\ Shandong Jiaotong University, Weihai, China
}

Keywords: nautical major; college English; independent learning; learning source dynamics

\begin{abstract}
This paper takes nautical students as the research object, based on the theory of independent learning and learning source dynamics, briefly introduces the current situation of college English teaching for maritime students, analyzes the students' learning situation and achievements, and summarizes the ability to cultivate independent learning. And the methods and strategies to stimulate the source of power have a certain significance for cultivating the lifelong learning ability of marine students and improving the competitiveness of the workplace.
\end{abstract}

\section{Introduction}

In 2007, the Ministry of Education issued the "Teaching English Course Requirements (Trial)", which marked the full implementation of the university English reform with the core of "ability" training. The goal of college English teaching has been changed from the traditional simple language knowledge and skills to Capacity acquisition; in June 2010, the 41st meeting of the World Maritime Organization Crew Training and Watchkeeping Standards (STW) Sub-Committee adopted the revised International Convention on Standards of Training, Certification and Watchkeeping for Seafarers (hereinafter referred to as the STCW Convention). highlighting the seafarers' effective communication and communication skills, and for the first time, the senior crew should have the ability to use English language for management, leadership, coordination, teamwork and decision-making, and to communicate and exchange information on ships in English. In 2012, the Ministry of Education and the Ministry of Transport jointly issued the "Several Opinions on Further Improving the Quality of Maritime Education". Under such a background, how to combine the reform of college English teaching with the improvement of the quality of maritime education, on the one hand, to train students The ability to use English comprehensively, on the other hand, enables students to continue to learn English autonomously after graduation and improve their competitiveness in the workplace. This is a key issue that our teachers need to consider. According to the principle of individualized teaching and the principle of teaching students in accordance with their aptitude, the university English of Dalian Maritime University is graded. The freshmen are enrolled in English after the entrance examination. According to the results, 25\% are selected, and then the students are tested in oral English. Students will stay in the English experimental class (four in each of the marine turbines, 30 per class), and complete 180 class hours in one academic year; the remaining students will be randomly assigned to regular classes and 180 hours in two academic years. In addition, all students who need to study independently include: selected articles in college English reading and writing textbooks; some listening materials in college English listening and speaking textbooks; campus broadcast English listening and 21st century English newspapers. Students in the English experimental class conduct experimental teaching. There are special experimental teaching materials. Online learning and evaluation tests can be conducted online. There is a fixed time to go to the self-learning classroom every week. The questions in the learning process can be submitted and feedback, and the teacher answers questions.

\section{Existing problems}

The current problems mainly exist in: (1) The gap in student level is large. College English class 
is too simple for a small number of students with high English proficiency, "not enough to eat", and a considerable number of students have a poor foundation in terms of pronunciation, vocabulary, grammar, and listening and speaking. It is a bit difficult to keep up with the rhythm of the teacher. (2) College English teaching and secondary education are not well matched. Due to the influence of traditional teaching concepts and exam-oriented education, most of the middle school English teaching in China adopts teacher-centered indoctrinating teaching, ignoring the cultivation of students' independent learning ability. After the students entered the university, they left the help and guidance of the parents and the teachers, and they became confused. They did not know what the goal of learning was and did not know how to complete the study. And cognitive psychology is strong: The acquisition of knowledge is mainly discovered by the learners themselves. Constructionist psychology emphasizes that students are the subjects in the learning process, as Johnson \& Morrow (1981) believes, teachers play The role can only be help, advice and guidance. The task of learning must be done by the learner itself. Therefore, from this point of view, the university stage can be regarded as a transitional stage from the passive learning of the middle school to the self-learning after work. In the meantime, how to develop students' self-learning ability is crucial.

\section{The cultivation of students' English self-learning ability}

\subsection{Enhance students' self-directed learning awareness and stimulate the source of students' learning}

After entering the school, the students of nautical majors will learn the speciality of the profession and the importance of English through various channels. The level of English may directly affect the pros and cons of future work. Therefore, they have the goal and potential to learn English well. Power source. However, many students believe that learning English is only for the examination of seafarers' certificates and job hunting. Once the work agreement is signed, they can not learn. Therefore, in teaching activities, teachers must first make students realize that self-directed learning is closely related to the effect of classroom teaching. After teachers complete the leading role in the classroom, whether students can truly master the knowledge and skills they have learned must rely on autonomy. Learn. Secondly, it is necessary to stimulate students' professional identity and pride from the frontiers of the industry and prospects for the development of the disciplines. It also invites outstanding seniors to share the successful experiences in employment and entrepreneurship, and play a role model to stimulate the students' inner motivation. At the same time, students should be guided to develop short-term and long-term English learning goals, which will run through the students' entire study and career development process.

\subsection{Create an effective environment for independent learning and improve the evaluation mechanism}

Students in the maritime class need a lot of English practice exercises. Therefore, the students should be centered on the students and develop the ability of students to think independently. Teachers should design various classroom activities according to the characteristics and level of students, fully mobilize each student to actively participate in the activities, and let the students complete the exercises of listening, speaking, reading and writing as much as possible. At the same time, continue to provide students with existing resources and conditions such as campus radio listening, English corner, 21st century English newspaper reading, [8] should also promote the online learning platform to all maritime students, and introduce applicable maritime English learning software and English learning resources in marine technology, regulations, etiquette, etc.

The author conducted two questionnaires for the 1,200 students of the University of Maritime University's nautical majors in 2014, and two students from the six regular classes, in October 2014 and July 2016, respectively. The proportion of self-learning students to the total number of students surveyed can be seen from Table 2. After two years of training, students have different degrees of growth in all aspects of self-learning compared to two years ago. Most of the students already have 
the awareness of self-directed learning, and they have basically developed a good habit of self-learning.

While stimulating and guiding students to learn independently, it is also necessary to establish a more comprehensive evaluation mechanism and teacher monitoring system to effectively supervise, answer questions and evaluate students. Students conduct self-reflection through teacher evaluation, self-evaluation and mutual evaluation. Improve learning methods and improve self-learning ability.

\subsection{Strengthen the training of strategies for English autonomous learning}

Holec believes that self-learning ability needs to be obtained through formal learning through natural or specialized channels. Therefore, the cultivation and training of autonomous learning ability is also a long-term process, and it is necessary to train students in learning strategies. There are three types of learning strategies: one is the method of memory, which is used to read the text of the text, and the other is the method of fine processing, which is used to deepen the understanding of the learning materials, including the summary of foreign languages, notes and strategies for asking questions; It is an organizational method that integrates the learned knowledge, adapts it, and links it with the original knowledge. These three types of strategies are gradual. Teachers should not only introduce these methods, but also train students to use strategies, encourage and guide students to adopt their favorite strategies. For example, organize students to communicate with each other, summarize the experience of English learning, and learn to use the evaluation system to evaluate or adjust their learning strategies. In addition, students should be guided to make reasonable use of resources such as reference books, reference books and various online media. Students can also design and organize dubbing, singing, debate, short play, speech, classic novel reading, simulation entrepreneurship and other activities or competitions, combined with a variety of extracurricular practices to apply and test their learning strategies, improve their ability to learn independently.

\section{The conclusion}

The concept of lifelong learning has gradually been accepted by the public, and the cultivation of college students' English self-learning ability has become the ultimate goal of college English teaching. College English teachers need to remember: "Teaching is not to teach." Students in the maritime majors cannot be satisfied with the status quo, but should take the opportunity of fulfilling the new STCW convention, gradually gain the ability of self-learning from the guidance of teachers, master the ability of English communication and application, regardless of whether they are in school or in society. All kinds of positions can be used with ease and benefit for the whole life, thus achieving the sustainable development of talents and schools.

\section{References}

[1] Johnson, K. \& K. Morrow. Communication in the Classroom [M]. London: Longman.

[2] Holec, Henry. Autonomy and Foreign Language Learning [M]. Oxford: Pergamon Press, 1981.

[3] Chen Haiyan. Cultivation of English Autonomous Learning Ability of Higher Vocational Navigation Students[J]. Journal of Hebei Energy Vocational and Technical College.2015.3.

[4] Li Yanhui. Analysis of the Ways to Cultivate College Students' Self-study Ability in English[J]. Education and Occupation, 2014, (5).

[5] Yan Ming. An Empirical Study on the Cultivation of College English Autonomous Learning Ability [J]. Foreign Language E-learning, 2010, (3).

[6] Gu Wenxiu. Exploring the motivation of active learning of college students[J]. Education and Teaching Forum, 2013, (02).

[7] Shi Min. Investigation and countermeasures of English autonomous learning ability of students in higher vocational colleges [J]. Maritime Education Research, 2012, (2). 